UDC: 547.314.316.784.546.847.862

\title{
HOMOGENEOUS VINYLATION OF 2-HYDROXY-2-PHENYLETHANICAL ACID
}

\author{
A.B.Parmanov ${ }^{1}$, S.E.Nurmanov ${ }^{1}$, Beata Kolesinsko ${ }^{2}$, Tomash Maniecki ${ }^{2}$, O.E. Ziyadullayev ${ }^{1}$ \\ ${ }^{I}$ National university of Uzbekistan, $t$. Tashkent \\ asqar.parmanov@mail.ru \\ ${ }^{2}$ Lodz University of Technology, Lodz, Poland
}

Received 29.06.2018

\begin{abstract}
Homogeneous-catalytic vinylation of 2-hydroxy-2-phenylethanical acid was carried out. The influence of the nature of the catalysts, the temperature and the duration of the reaction on the yield of the synthesized vinyl ether was studied.
\end{abstract}

Keywords: almondsal acid, acetylene, heterogeneous catalysis, influencing factors on product yield, catalysts: $\mathrm{AlCl}_{3} \cdot 6 \mathrm{H}_{2} \mathrm{O}$ and $\left.\left(\mathrm{C}_{6} \mathrm{H}_{5} \mathrm{CH}(\mathrm{OH}) \mathrm{COO}\right)_{2} \mathrm{Zn}\right)$.

doi

\section{Introduction}

Vinyl ethers are important compounds, since due to the presence of a double bond and an ether group in their molecules, various chemical transformations can be carried out on their basis. Such compounds are widely used in the preparation of dyes and in the production of monomers for the synthesis of various polymers. Known methods for producing compounds by various chemical transformations of the double bonds of vinyl esters of carbonic acids, their polymers and copolymers were used to create effective emulsifiers and dyes. Similarly, materials that improve the viscosity of lubricants and crosslinking agents for the rubber industry have also been obtained. Currently, high demands on polymeric materials are associated with the expediency of improving the quality of products and their cost. From this point of view, the use of natural compounds for similar purposes is also very important $[1,2]$.

Part of the almond-2-hydroxy-2-phenylethanical acid (almondsal acid) is a natural compound. On its basis, antiseptics have been obtained, which are used in medicine as starting compounds for the production of antibiotics. Currently, ammonium and calcium salts of almondsal acid are used as urogenic substances in urology. It is also used as an analytical reagent for the determination of ions $\mathrm{Ti}, \mathrm{Fe}, \mathrm{Al}, \mathrm{Cr}, \mathrm{V}$ and for the separation of $\mathrm{Zn}$ from Mo [3-5]. The acidic properties of the acid under study are higher compared to acetic acid, which affects its biological activity and the limited scope of its use. For this reason, a decrease in its acidic properties allowed us to increase the biological activity of almondsal acid.

\section{Experimental part}

Homogeneous catalytic vinylation of almondsal acid was carried out in a solution of dimethyl sulfoxide (DMSO) in the presence of catalyst composition, containing zinc salt of almondsal acid and $\mathrm{AlCl}_{3} \cdot 6 \mathrm{H}_{2} \mathrm{O}$ at a temperature of $80-140^{\circ} \mathrm{C}$. Acetylene was passed through a mixture of almondsal acid and catalyst in DMSO with a speed of $0.1 \mathrm{~mol} / \mathrm{h}$. The almond acid vinyl ester was formed as the main product according to the following reaction scheme:

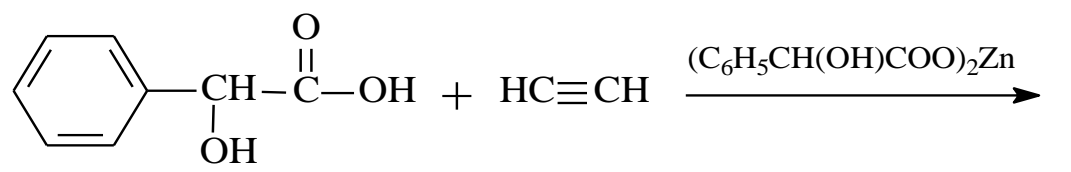<smiles>C=COC(=O)C(O)c1ccccc1</smiles> 
The resulting ester is a new organic compound, unknown in the literature.

\section{acid}

\section{Vinyl of 2-hydroxy-2-phenylethanical}

Yield - 84.4\%. IR (KBr): 3430, 3003, 2917, 1712, 1663, 1407,1210, 1025, 901. ${ }^{1} \mathrm{H}-$ NMR, $\delta, p p m\left(400 \mathrm{MHz}, \mathrm{CDCl}_{3}\right): 7.33-7.53$ $(6 \mathrm{H}, 7.47$ (dd, $J=14.8,7.8 \mathrm{~Hz}), 7.45$ (dtd, $J=8.4$, $1.2,0.5 \mathrm{~Hz}$ ), 7.38 ( dddd, $J=8.4,7.4,1.6,0.5$ $\mathrm{Hz}), 7.36$ (tt, $J=7.4,1.3 \mathrm{~Hz}), 6.00(1 \mathrm{H}, \mathrm{s}), 5.14$ $(1 \mathrm{H}, \mathrm{dd}, J=14.8,2.3 \mathrm{~Hz}), 5.06(1 \mathrm{H}, \mathrm{dd}, J=7.8$, $2.3 \mathrm{~Hz})$.

${ }^{13} \mathrm{C}$ NMR $\left(100 \mathrm{MHz}, \mathrm{CDCl}_{3}\right): 171.5$, $141.3,138.6,128.9,126.6,128.5,98.2,73.0$

\section{Results}

Temperature significantly influenced the catalytic reaction under investigation. For this reason, the effect of temperature on the vinylation of almondsal acid by acetylene was investigated. The results are presented in Table 1.

Table 1. Influence of temperature on vinylation of almondsal acid in the presence of zinc salt of almondsal acid $(10 \%)$ (Rate of acetylene -0.1 mole/h)

\begin{tabular}{|c|c|}
\hline $\begin{array}{c}\text { Temperature of reaction, } \\
{ }^{0} \mathrm{C}\end{array}$ & $\begin{array}{c}\text { Yield of vinyl ester, } \\
\%\end{array}$ \\
\hline 80 & 45.8 \\
\hline 90 & 49.4 \\
\hline 100 & 56.6 \\
\hline 110 & 63.2 \\
\hline 120 & 65.9 \\
\hline 130 & 61.5 \\
\hline 140 & 53.4 \\
\hline
\end{tabular}

As the results obtained showed, temperature had a great influence on the vinylation of almondsal acid by acetylene. In the investigated temperature range of $80-140^{\circ} \mathrm{C}$, vinyl ether is formed, the output of which varies with temperature. An increase in temperature from 80 to $120^{\circ} \mathrm{C}$ leds to an increase in the yield of the product from 45.8 to $65.9 \%$, and a subsequent increase in temperature to $130^{\circ} \mathrm{C}$ leds to a decrease in it, while also decomposing DMSO with formation of sulfur-containing compounds with following formation cross-linking oligomeric products.

For vinylation of almondsal acid with acetylene, the optimum temperature was $120^{\circ} \mathrm{C}$, and the yield of the vinyl ester formed was $65.9 \%$, and accordingly the following studies were carried out at this temperature.

Table 2 presents the results on the effect of temperature on the vinylation of almond acid in the presence of its zinc salt and $\mathrm{AlCl}_{3} \cdot 6 \mathrm{H}_{2} \mathrm{O}$ $(10 \%)$ as a catalyst.

Table 2. Influence of temperature on vinylation of almondsal acid in the presence of [Zinc salt $+\mathrm{AlCl}_{3} \cdot 6 \mathrm{H}_{2} \mathrm{O}$ $(10 \%)$ ] catalyst (time-2 h, rate of acetylene past through $0.1 \mathrm{~mole} / \mathrm{h})$

\begin{tabular}{|c|c|}
\hline $\begin{array}{c}\text { Temperature of reaction, } \\
{ }^{0} \mathrm{C}\end{array}$ & $\begin{array}{c}\text { Yield of synthesised vinyl } \\
\text { ester, } \%\end{array}$ \\
\hline 80 & 65.3 \\
\hline 90 & 68.7 \\
\hline 100 & 69.6 \\
\hline 110 & 73.9 \\
\hline 120 & 79.8 \\
\hline 130 & 67.5 \\
\hline 140 & 63.4 \\
\hline
\end{tabular}

From obtained results show that in presence of elaborated catalyst in temperature range $80-120^{\circ} \mathrm{C}$ yield of forming vinyl ester of almondsal acid has increased from 65.3 to 79.8 and presence of $\mathrm{AlCl}_{3} \cdot 6 \mathrm{H}_{2} \mathrm{O}$ in composition of catalyst has increased the catalytic activity.

It is known, that in the steady state the duration of the reaction (time) plays a very important role. For this reason, the influence of this factor on the formation of the main product - almondsal vinyl ester was investigated and the results obtained are presented in Table 3.

Table 3. Influence of process duration on vinylation of almondsal acid in the presence of Zink salt catalyst (rate of feeding of acetylene $0.1 \mathrm{~mole} / \mathrm{h}$, temperature $120^{\circ} \mathrm{C}$ )

\begin{tabular}{|c|c|}
\hline $\begin{array}{c}\text { Duration of reaction, } \\
\mathrm{h}\end{array}$ & $\begin{array}{c}\text { Yield of vinyl ester of al- } \\
\text { mondsal acid, } \%\end{array}$ \\
\hline 1 & 48.7 \\
\hline 2 & 65.9 \\
\hline 3 & 69.7 \\
\hline 4 & 71,1 \\
\hline 5 & 69.8 \\
\hline 6 & 67.2 \\
\hline
\end{tabular}

It is shown, that the yield of the obtained vinyl ether increased accordingly from 48.7 to $71.1 \%$ with an increase in reaction time from 1.0 to 4.0 hours, but with a further increase in the duration of the reaction, the yield of the 
product decreased by $1.3-2.6 \%$. Thus, $4 \mathrm{~h}$ is the optimal duration of the test reaction. According to the chromatographic analysis at the time of the 3-hour reaction, no initial almondsal acid was detected in the reaction products. During the reaction for more than 4 hours, the formation of rubber-like compounds was also observed due to oligomerization and polymerization of the obtained vinyl ether and its crosslinking with $\mathrm{H}_{2} \mathrm{~S}$ as a result of decomposition of the DMSO. Influence of process duration on vinylation of almondsal acid in the presence of catalyst at $120^{\circ} \mathrm{C}$ and rate feeding of acetylene $0.1 \mathrm{~mol} / \mathrm{h}$ are presented in Table 4 .

Table 4. Influence of duration of vinylation almondsal acid in the presence of [Zinc salt $+\mathrm{AlCl}_{3} \cdot 6 \mathrm{H}_{2} \mathrm{O}(10 \%)$ ] catalyst at temperature $120^{\circ} \mathrm{C}$ and rate feeding of acetylene $0.1 \mathrm{~mol} / \mathrm{h}$

\begin{tabular}{|c|c|}
\hline $\begin{array}{c}\text { Duration of reaction, } \\
\mathrm{h}\end{array}$ & $\begin{array}{c}\text { Yield of vinyl ester of al- } \\
\text { mondsal acid, } \%\end{array}$ \\
\hline 1 & 56.5 \\
\hline 2 & 79.8 \\
\hline 3 & 83.2 \\
\hline 4 & 84.4 \\
\hline 5 & 82.9 \\
\hline 6 & 81.1 \\
\hline
\end{tabular}

From the data of table 4 it can be seen, that the introduction of the ingredient $\mathrm{AlCl}_{3} \cdot 6 \mathrm{H}_{2} \mathrm{O}$ into the composition of the catalyst increased its activity due to the fact that it acts as a promoter. In the presence of this catalyst, the yield of vinyl ether for 1-4 hours increased from 56.5 to $84.4 \%$.

\section{Conclusions}

It was shown that when almond acid was vinyllated with acetylene in the presence of a catalyst $\left(\mathrm{C}_{6} \mathrm{H}_{5} \mathrm{CH}(\mathrm{OH}) \mathrm{COO}\right)_{2} \mathrm{Zn}$, its vinyl ether was formed.

It has been established that the introduction of the catalyst $\mathrm{AlCl}_{3} \cdot 6 \mathrm{H}_{2} \mathrm{O}(10 \%)$ as a promoter into the catalyst composition led to an increase in the yield of the vinyl ether formed.

It was found that the temperature, the duration of the reaction and the nature of the catalyst used have a great influence on the yield of almond acid vinyl ester.

\section{References}

1. Parmanov A.B., Nurmanov S.E., Phayzullaeva M.Ph., Abdullaev J.U., Soliev M.I. Synthesis of vinyl esters of some carbonic acids. Aust. J. Tech. Nat. Sci. 2017. No 1-2. P. 129-132.

2. Ioan-Teodor Trotus, Tobias Zimmerman, Ferdi Schuth. Catalytic reactions of acetylene. A Feedstock for the Chemical industry revisited. Chem. Rev. 2014. V. 114. P. 1761-1782.

3. Stanley R., Sandler. Atmospheric vinylation of several haloacetic acids and benzoic acid by acetylene. J. Chem. Eng. Data. 1973. V. 18. No 4. P. 445-448.

4. Suming Ye, Weng Kee Leong. Synthesis and structure of some ruthenium-rhenium heterodinuclear complexes and their catalytic activity in the addition of carboxylic acids to phenylacetylene. J. Organomet. Chem. 2006. V. 691. No 6. P. 1216-1222.

5. Francisco Alonso, Irina P. Beletskaya, Miguel Yus. Transition-metal-catalyzed addition of heteroatom-hydrogen bonds to alkynes. Chem. Rev. 2004. V. 104. No 6. P. 3079-3160.

\section{ГОМОГЕННОЕ ВИНИЛИРОВАНИЕ -2-ГИДРОКСИ-2-ФЕНИЛЭТИЛОВАЯ КИСЛОТА}

\section{А.Б.Парманов, С.Е.Нурманов, Беата Колесинско, Томаш Маниески, О.Е.Зиядуллаев}

Проведено гомогенно-каталитическое винилирование 2-гидрокси-2-фенилэтиловой кислоты. Изучено влияние природы катализаторов, температура и продолжительности реакции на выход синтезированного винилового эфира.

Ключевые слова: миндальная кислота, ацетилен, гетерогенный катализ, влияющчие факторы на выход продукта, катализаторы: $\mathrm{AlCl}_{3} \cdot 6 \mathrm{H}_{2} \mathrm{O}$ и $\left(\mathrm{C}_{6} \mathrm{H}_{5} \mathrm{CH}(\mathrm{OH}) \mathrm{COO}\right)_{2} \mathrm{Zn}$.

\section{2-HIDDROKSİ-2-FENILETIL TURŞUNUN HOMOGEN VIINILLDŞDİRILLMSII}

\section{A.B.Parmanov, S.E.Nurmanov, Beata Kolesinsko, Tomash Maniecki, O.E.Ziyadullayev}

2-Hidroksi-2-feniletil turşunun homogen vinilləşdirilməsi aparılmışdır. Karalizatorun təbiətinin, temperaturun və reaksiya müddətinin sintez olunmuş vinil efirinin çıxımına təsiri öyrənilmişdir.

Açar sözlor: badam turşusu, asetilen, heterogens kataliz, məhsulun çıxımına təsir elən amillar, katalizatorlar: $\mathrm{AlCl}_{3} \cdot 6 \mathrm{H}_{2} \mathrm{O}$ va $\left.\left(\mathrm{C}_{6} \mathrm{H}_{5} \mathrm{CH}(\mathrm{OH}) \mathrm{COO}\right)_{2} \mathrm{Zn}\right)$. 